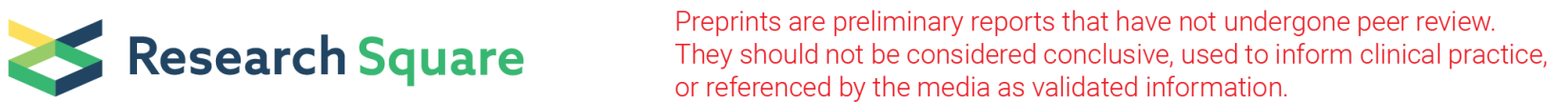 \\ Treatment of Polluted Urban Surface Waters by Sponge Based Aerobic Biofilm Reactor: Purification Performances and Resilience
}

\section{Shangwei He}

Chinese Academy of Sciences

Na Song

Chinese Academy of Sciences

Zongbao Yao

Chinese Academy of Sciences

Helong Jiang ( $\sim$ hljiang@niglas.ac.cn )

Nanjing Institute of Geography and Limnology, Chinese Academy of Sciences

\section{Research Article}

Keywords: Surface waters, Polyurethane sponge, Filling ratios, Ammonium, Function resilience

Posted Date: October 1st, 2021

DOI: https://doi.org/10.21203/rs.3.rs-837749/v1

License: @ (1) This work is licensed under a Creative Commons Attribution 4.0 International License. Read Full License 


\section{Abstract}

Surface waters are suffering continuous discharging of pollutions, and low DO and black-odorous were easily formed, especially in those slow-flowing urban lakes and enclosed small ponds. In-situ treatment by artificial aeration or water cycling with a combination of polyurethane sponge as biofilm carriers can disentangle this situation without any land occupation. Long-term continuous experiments (187 days) showed that indigenous microorganisms in urban surface waters could form biofilms in the novel style of sponge-based aerobic biofilm reactors (SABRs). In urban lake waters treatment, the purification performances of SABRs were stable and resilient as the $\mathrm{NH}_{4}{ }^{+}-\mathrm{N}^{-}$and $\mathrm{NO}_{2}{ }^{-}-\mathrm{N}$ removals were steady, even facing the abrupt increase of $\mathrm{NH}_{4}{ }^{+}-\mathrm{N}_{\text {and }} \mathrm{NO}_{2}{ }^{-}-\mathrm{N}$ concentrations in influent. Enhancing the polyurethane sponge filling ratios in SABRs can reduce $\mathrm{DO}$ but did not affect $\mathrm{NH}_{4}{ }^{+}-\mathrm{N}$ removal. SABRs were also able to treat enclosed surface waters or black-odorous waterbodies. Combined SABRs with water cycling, $\mathrm{NH}_{4}{ }^{+} \mathrm{N}$ removal time was shorter than the time needed by water cycling when biodegradable organic matter was not present. The massive biodegradable organic matter could inhibit nitrification and prolong the purification time. Further results showed that organic matter could be used as carbon sources to eliminate the produced $\mathrm{NO}_{3}{ }^{-} \mathrm{N}$ in SABRs. Therefore, the developed new bioreactor could act as one effective way for treating $\mathrm{N}$-polluted urban surface waters.

\section{Introduction}

Due to rapid economic development and population increase, surface waters are suffering excess nutrition discharged from municipal and agricultural drainage (Nsenga Kumwimba et al. 2018). Continuous nutrition inflow to the surface waters can potentially damage the ecosystems, and lead to low dissolved oxygen (DO), submerged aquatic plant disappearance (Yan et al. 2019), algae bloom (Wu et al. 2016), especially in those slow-flowing surface waters like urban lakes and/or enclosed small ponds (Hobbie et al. 2017).

Phosphorus in surface waters can be removed by chemical adsorption and precipitation (Funes et al. 2018; Min et al. 2020; Wang et al. 2018a; Wu et al. 2019b; Xiong and Peng 2008). Nitrogen removal from actual surface waters was difficult as it needs to combine nitrification and denitrification (Xia et al. 2017). Abiotic environmental conditions will affect nitrification and denitrification (Austin et al. 2019; Yang et al. 2019; Zhang et al. 2014), such as DO, temperature, pH, and ammonium concentration $\left(\mathrm{NH}_{4}{ }^{+}-\mathrm{N}\right)$. DO in surface waters can be easily consumed by organic matter, then favoring denitrification and restraining the critical ammonium nitrification. Even more, stormwater runoff suddenly increases contaminant loading to surface water (Zhao et al. 2015), and the effluent of wastewater water treatments in cold seasons often contains relatively higher $\mathrm{NH}_{4}{ }^{+}-\mathrm{N}$ than that in warm seasons (He et al. 2018), which may affect the surface water qualities and hydrobios.

Many physicochemical and biological approaches have been used to remove nutrients from polluted water before flowing to the surface waters. Wetlands (Austin et al. 2019; Ballantine et al. 2014; Saeed et al. 2019), vegetated drainage ditches (Nsenga Kumwimba et al. 2018), riparian buffer strips, and integrated buffer zones (Zak et al. 2018) can mitigate the adverse impacts of high nutrient loading with performance being better during the warm season. But these methods generally need a large scale of land (Liu et al. 2016) and limit their use in urban areas. Hence, in-situ treatment by floating beds was acceptable, and the combination of the plants with biofilm bacterial communities can enhance the removal rate without occupying land areas (Liu et al. 2016; Wang et al. 2018b; Wu et al. 2016; Zhang et al. 2015). However, floating beds were vulnerable to the season change (Liu et al. 2016), and most plants would die and the residues should be removed to avoid the second pollution during the cold season.

Polyurethane sponge is a synthetic polymer hydrophilic biological carrier and an ideal growth medium for biofilm formation (Feng et al. 2012; Guo et al. 2010; Zhang et al. 2016). It has been used in wastewater treatment to enhance nitrogen removal due to the high DO gradient in the cubic biofilms (Feng et al. 2012), and different filling ratios can affect 
the removal effectivity (Feng et al. 2012; Guo et al. 2010; Zhang et al. 2016; Zhao et al. 2019). Anaerobic biofilms on polyurethane also can enhance the biodegradation of refractory compounds (Shi et al. 2019). When cultured on polyurethane sponges, the mix-aerobic denitrifiers can effectively remove nitrogen in actual reservoir source water (Zhou et al. 2016). But little is known about the use of polyurethane sponges in urban surface waters.

Functional resilience of a reactor is critical in practice use, as the environmental conditions often change and may affect the treatment abilities. Thus it is needed to determine how bioreactors are able to cope with disturbance and recover after disturbance (Boog et al. 2018; Cabrol et al. 2012; Cho et al. 2016; Sukias et al. 2018). Previous research found that it took 14 days to completely recover nitrification under ammonia shock loading for steel wastewater treatment (Cho et al. 2016). However, there were seldom reports focusing on the resilience of a reactor in treating urban surface waters.

In this study, a novel style of biofilm reactor was developed to purify urban surface waters under various conditions. Polyurethane sponges were used as carriers to enrich the indigenous microorganisms to form biofilms, and the micropolluted urban lakes and enclosed surface waters such as those small ponds in sub-districts were taken as study objects. We prospected that cultured biofilms can benefit contaminant removal in urban surface waters. The objectives of this study were: 1) to develop aerobic biofilm reactors with polyurethane sponge as carriers; 2) to check the resilience of function by suddenly increasing $\mathrm{NH}_{4}{ }^{+}-\mathrm{N}$ or $\mathrm{NO}_{2}-\mathrm{N}$ concentrations in influent; 3 ) to investigate the purification performances of biofilm reactors for enclosed-surface water treatment.

\section{Materials And Methods}

\section{Aerobic biofilm reactor set-up}

Cubic-shaped polyurethane sponges $(10 \times 10 \times 10 \mathrm{~mm})$ served as biofilm carriersin this study, purchased from AiQin Environmental Technology Co., Ltd., Jiangsu,China. The average specific surface area of a sponge cube was $91,000 \mathrm{~m}^{3} \mathrm{~m}^{-}$

2 , and the porosity was $95 \%$.

Sponge-based aerobic biofilm reactors (SABRs) were set in 100L plastic buckets and simulated as treat urban surface waters(Fig.1a).The effective volume of the plastic bucket was 80L.Each SABR consisted of anup-flow zoneand threebiofilm zones, all made by acrylics cylinder with $100 \mathrm{~mm}$ inner diameter. The up-flow zone was $600 \mathrm{~mm}$ in height, and biofilm zones were $280 \mathrm{~mm}$ in length (consisting of a $100 \mathrm{~mm}$ cylinder and a $180 \mathrm{~mm}$ cone) (Fig. $1 \mathrm{~b}$ ). Three biofilm zones were connected with the up-flow zoneand arranged $120^{\circ}$ between themselves (Fig.1c).The top of the up-flow zone was sealed with a conical acrylic plate to prevent water from flowing out of the up-flow zone and flow the surface wateraveragely into the three biofilm zones.Fine iron wires were arranged in the connection area to prevent the carriers from dropping off when introduced into biofilm zones.Small holes were made at the top of the biofilm area to circulate the surface water and prevent the internal carriers from being washed away. This special design considered that in practical application, the reactorswill be placed in the middle of the surface water and reduce the interference of the surrounding people.

Polyurethane spongeswere filledonly in the biofilm zones, and the filling ratiosin biofilm zones were the same in one SABR. Filling ratios of $20 \%, 40 \%, 60 \%$ and $80 \%$ were adopted andreferred to as FR20, FR40, FR60, and FR80, respectively. The filling ratios in this study werebased on the volume of the biofilm zone, which is different from previous studies as those filling rates were based on the whole reactor(Zhang et al. 2016; Zhao et al. 2019).

\section{Reactor operating conditions}

\section{Purification performances and resilienceintreatment of urban lake waters}


The urban lakes are the receiving watersfor urban pollution, such as the effluents from the wastewater treatment plants. Thus the experiment was fed with continuous flow.Surface waters were collected to laboratory every week from Lake Xuanwu, located in Nanjing City (China). The operation was dividedinto three stages (Table1).Influents were continuously fed to reactors by peristaltic pumps $\left(6.95 \mathrm{mlmin}^{-1}\right)$, and hydraulic retention time (HRT) was 8 daysasthe HRT of Lake Xuanwu was about 7 days.Ammonium chloride $\left(\mathrm{NH}_{4} \mathrm{Cl}\right)$ was added to the lake waters(collected from Xuanwu Lake) to

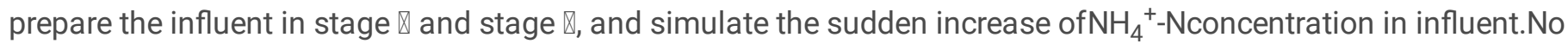
sediments were added into the buckets as dredgingis often adopted in urban lakes, such as Lake Xuanwu.After dredging,the organic carbon contents in the surface layer of sediment were low and denitrification was inhibited(Zhong et al. 2009).

Stage I:This stage was used to enrich the indigenous microorganisms to form biofilms on bio-carriersand study the purificationperformances of SABRs forurban lakes. Actual surface water wascontinuously fed to SABRs without any nutrition addition. DO supply by controlled airflow with $60 \mathrm{mLmin}^{-1}$ and lasted for 70 days (Stage冈-a).Submersible waterpumps (Tian Xia Yu Jia, TA8800, 2000 Lh ${ }^{-1}$ ) were used in Stage区-b for enhancing the hydraulic condition and lasted for 37 days.

Stage $₫:$ This stage wasused to study the function resilience of SABRs as rainfallmay lead to non-point pollution flow into urban lakes,which often occurred in warm seasons. Nitrogen fertilizer is often used for urban landscaping.During the warm and rainy season, the nitrogen fertilizer will flow into the urban lake.Previousstudies found thatlow organic loading was favorable fornitrification(Luo and Meng 2020). However, most organic matters in surface runoff arehumic-like compoundsand are difficult to biodegrade(Zhao et al. 2015).Moreover,the dissolved organic carbon in surface water was only 2.03-7.67 $\mathrm{mgL}^{-1}$, and the bioavailable organic carbon only accounting for 6\%-11\%(Wu et al. 2019a; Xu et al. 2020). Thus only $\mathrm{NH}_{4}{ }^{+}$-Nconcentrationsin influentwereintermittentlyimproved to $2.00-4.00 \mathrm{mgL}^{-1}$ for 7 times.

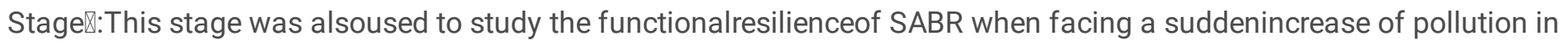

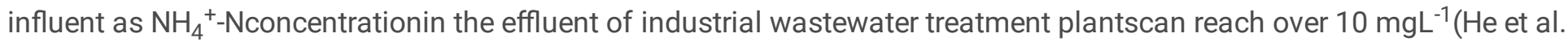
2018). The organic mattersin wastewater treatment plantscan beremoved stably and effectively, and the organic matters in effluent were often refractory. Thus only $\mathrm{NH}_{4}{ }^{+}$-Nconcentrationincreased suddenlyto $15.00 \mathrm{mgL}^{-1}$ in influent and smoothly declined for 16 days, followed by influent as in stage $\otimes\left(3.26 \mathrm{mgL}^{-1} \mathrm{NH}_{4}{ }^{+}-\mathrm{N}\right)$ for 7 days.

\section{Purification performancesfor treatment of enclosed surface waters}

Synthetic waters were usedto simulate the enclosed surface waters,which often contain high concentrations of organic matters and $\mathrm{NH}_{4}{ }^{+}-\mathrm{N}$ with black-odorous appearances (such as those small ponds in subdistricts and parks). Duo to no continuous discharge into those enclosed surface waters, batch experiments wereadopted and to examine whether the biofilms cultured byurban lake waters can directlybe used in those stagnant waters. Control and only hydraulic circulation were also set up(same plastic buckets with $80 \mathrm{~L}$ effective volume).As organic matter may not be present in some enclosed surface waters, two operating conditions were applied in the experiments.

No organic matterspresent: $\mathrm{NH}_{4}{ }^{+}$-Nconcentrations wereimproved to about $14 \mathrm{mgL}^{-1}$ throughNH $\mathrm{Cl}_{4}$ addition. $\mathrm{NO}_{3}{ }^{-}$Nconcentration was improved to $1.85 \pm 0.10 \mathrm{mgL}^{-1}$ to test whether denitrification can occur naturally in the control treatment.Before experiments, $\mathrm{pH}$ was adjusted to $7.68 \pm 0.03$ by $\mathrm{NaHCO}_{3}$ addition (Table 1 ).

Organic matters present:Acetic acid and glucose (at a ratio of $1 \otimes 1$ by chemical oxygen demand) were added into water to simulatethose black-odorous waterbodies (TOC $59.56 \pm 3.09 \mathrm{mgL}^{-1}$ ) before experiments. Other characters of surface waters wereslightly higher than no organic matters present (Table 1). 
Due to low DO and high organic matters in surrounding untreated surface waters, it is beneficial for denitrificationandremoving the produced $\mathrm{NO}_{3}{ }^{-}-\mathrm{N}$ by SABRs. Thus batch experiments were used to removeNO${ }_{3}{ }^{-} \mathrm{N}^{-}$by mixing the effluent from SABR with the untreated surface waters. The mix ratios were $10 \%, 20 \%$, and $50 \%$. Twocontrols were also adopted (effluent of SABR and untreated surface waters). The mixed waters were not purged with $\mathrm{N}_{2}$ and were open to air during the experiments. Each treatment was repeatedtwo times.

\section{Analytical methods}

Samples were taken from the outflowand immediatelyfiltered through $0.45 \mu \mathrm{mpore}$ sizefiltersthen stored in $-20^{\circ} \mathrm{C}$ until analysis. The concentrations of $\mathrm{NH}_{4}{ }^{+}-\mathrm{N}, \mathrm{NO}_{2}{ }^{-}-\mathrm{N}, \mathrm{NO}_{3}{ }^{-}-\mathrm{N}, \mathrm{PO}_{4}{ }^{3-}-\mathrm{P}, \mathrm{TN}$, and TP were determined in accordance with standard methods(SEPA 2002). The DO, water temperature, and $\mathrm{pH}$ were in situ measured by a dissolved oxygen analyzer(YSI 5000, USA) and a digital pH meter (PB-10, Sartorius,Germany), respectively.Dissolved organic carbon concentrations(DOC) were measuredbya TOC analyzer (Torch- Teledyne Tekmar).

\section{Statistical analyses}

To compare the removal efficienciesofdifferenttreatments, one way-ANOVA followed by Tukey HSD post-hoc test was conducted by using SPSS software with significance considered at $P<0.05$ (SPSS Statistics version 20.0).

\section{Results And Discussion}

\section{Performance of SABRsintreating urban lake waters}

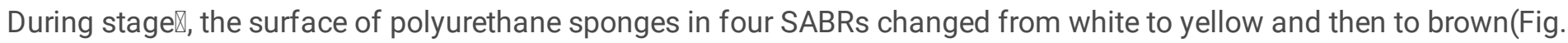
S1), indicating thatbiofilmswereformed by the indigenous microorganismsin urban surface waters.Artificial aeration and water cycling were often used in surface water purification, as these methods can improve the DO and change the hydraulic condition(Cao et al. 2020). DO values in four buckets were improved to over $5.00 \mathrm{mgL}^{-1}$ (Fig. 2a), whichbenefitted $\mathrm{NH}_{4}{ }^{+}-\mathrm{N}$ removal. With artificial aeration,DO concentrations in reactors did not show significant difference among the different filling ratios. Wherever, DO concentrationsdeclined with the filling ratios when water cycling was applied to change hydraulic conditions(Fig.2a).

Within 20 days of experiments, $\mathrm{NH}_{4}{ }^{+}-\mathrm{N}$ and $\mathrm{NO}_{2}{ }^{-}$-Nconcentrations in effluent of four reactors increased to $0.40-0.60 \mathrm{mgL}$ ${ }^{1}$ and $0.05-0.10 \mathrm{mgL}^{-1}$, respectively, andthen declined close to $0 \mathrm{mgL}^{-1}$ (Fig. 3a, b). Filling fraction had only a slight influence on $\mathrm{NH}_{4}{ }^{+}-\mathrm{N}$ removal, which consisted with usingpolyurethane spongesin MBBR for treating synthetic domestic wastewater(Zhang et al. 2016), but contradictedwiththeeffect of packing rates on $\mathrm{NH}_{4}{ }^{+}-\mathrm{N}$ removal(Feng et al. 2012),due to the characters of synthetic wastewater with high COD in that study.

$\mathrm{NO}_{3}{ }^{-}$-Nconcentrations of the four SABRs increased from $0.79 \mathrm{mgL}^{-1}$ to $0.95-1.13 \mathrm{mgL}^{-1}$ (Fig. S2a), and no TN removalswere observed (Fig. S2b), which means denitrificationswereinhibitedduring the experiment. Recently, some studies suggestedthatdenitrification canoccur in oxic waters,which ascribed to theheterogeneity microstructure of suspended sediments(Jia et al. 2016; Liu et al. 2013; Xia et al. 2017) and the aboundingappearanceof periphytic biofilms (Wu et al. 2014). However, denitrificationwas not observed in thisstudy because of the high DO and low nutrient level inlake waters.Firstly, denitrification could occurwhen DO concentration was up to $4.00-5.00 \mathrm{mgL}^{-1}$, and the denitrification rate decreased with an increase of DO levels(Wang and Chu 2016). In the continuous flow stages, DO values in the bulk liquid were higher than $5.00 \mathrm{mgL}^{-1}$, which could restraindenitrification. Secondly, traditional denitrification used organic compounds as carbon sources (Wang and Chu 2016),and simultaneous nitrification/denitrification can be achieved in wastewater treatment under continuous aerationwhen carbon source was enough(Macedo et al. 2019). But TOC in the 
water of Lake Xuanwuwas only $2.03 \mathrm{mgL}^{-1}(\mathrm{Xu}$ et al. 2020), and most of the TOC in lake waters were recalcitrant to biodegradation(Koehler et al. 2012). Thirdly, thoughaerobic denitrifying microbeshave been isolated and identified from lakes, reservoir sediments(Huang et al. 2013; Wen et al. 2019; Yao et al. 2020; Zhou et al. 2016; Zou et al. 2014), and aerobic denitrificationwas observed in a drinking waterreservoir by indigenous aerobic denitrifiers via in situ oxygen enhancement(Zhou et al. 2016; Zhou et al. 2020). But aerobic denitrifiers also need carbon sourcesfordenitrification (Wen et al. 2019; Xia et al. 2020). Our previous studies have shown that Penicilliumtropicum, an aerobic denitrifying fungus, requires $5.80 \mathrm{mgL}^{-1} \mathrm{TOC}$ to remove $1.00 \mathrm{mgL}^{-1} \mathrm{NO}_{3}{ }^{-} \mathrm{N}$ in aerobic condition(Yao et al. 2020). Lastly, phosphorus deficiency would also inhibit denitrification (Fan et al. 2018; Zhou et al. 2016), as the phosphorus concentrations in influent were only about $0.05 \mathrm{mgL}^{-1}$ (Fig. S2c).

\section{Resilience ofSABRswith suddenincrease of $\mathrm{NH}_{4}{ }^{+}-\mathrm{Nconcentrations} \mathrm{in} \mathrm{influent} \mathrm{of} \mathrm{urban} \mathrm{lake} \mathrm{waters}$}

With a slight increase of $\mathrm{NH}_{4}{ }^{+}-\mathrm{N}$ concentrations in influent in stage区, DO in the four SABRs was lower than that in stage $\$ and declined with the filling ratios (Fig. 2a). With the first sudden increase of $\mathrm{NH}_{4}{ }^{+}$-Nconcentrationin influent(in stage区), $\mathrm{NH}_{4}{ }^{+}-\mathrm{N}$ and $\mathrm{NO}_{2}{ }^{-}$-Nconcentrationsin effluentincreased slightly then declined close to 0 within 4-6 days and 4-8 days (Table 2), which were similar to the result under shorting HRT(Chang et al. 2019), aeration interruption(Boog et al. 2018; Murphy et al. 2016), and shock loading of influent (Cabrol et al. 2012; Cho et al. 2016; Sukias et al. 2018).

Subsequently, the concentration of $\mathrm{NH}_{4}{ }^{+}-\mathrm{N}$ and $\mathrm{NO}_{2}{ }^{-}-\mathrm{N}$ concentrations in the influent discontinuouslyincreased abruptly for six times,also the concentrations of $\mathrm{NH}_{4}{ }^{+}-\mathrm{N}$ and $\mathrm{NO}_{2}{ }^{-}-\mathrm{N}$ in the effluent firstlyincreased abruptly and then decreased.The periodsfor $\mathrm{NH}_{4}{ }^{+}-\mathrm{N}$ and $\mathrm{NO}_{2}{ }^{-}$-Nconcentrations to return to the previous stable state were shortened from 4-6 days to 0-4 daysand from 4-8 daysto 0-3 days,respectively(Table 2). One exceptionwas that it took 8 days to reduceNO ${ }_{2}^{-}-$ Nconcentrationto below $0.01 \mathrm{mgL}^{-1}$ in FR2O becauseNO ${ }_{2}^{-}$-Nconcentrations in the $4^{\text {th }}$ shock loading weremuch higher than previousshocking loadings(Fig. 3b; Table 2). These resultswere similar tothe nitrification reactor treating steel wastewater.After the first shock loading, it took 14 days to recover nitrification,but only needed 1 day after the second and third $\mathrm{NH}_{4}{ }^{+}-\mathrm{N}$ shock loading(Cho et al. 2016). When $\mathrm{NH}_{4}{ }^{+}-\mathrm{N}$ concentrationsin influent suddenly increased to $15.00 \mathrm{mgL}^{-1}$ in

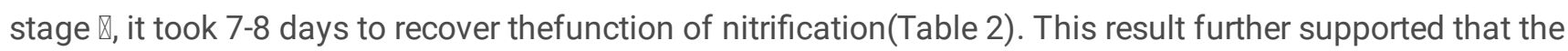
SABRsfunctionwas robust tovarious disturbances, which could be related to adaptation to fluctuating environmental conditions (Berga et al. 2017).In addition, the influent nitrifiermay be related to the resilience of SABRs, as the response of bacterial communities to disturbances can be affected by the dispersal(Yu et al. 2018), and the long HRT may also play an important roleas it can dilute the $\mathrm{NH}_{4}{ }^{+} \mathrm{N}$ concentration in surface water.

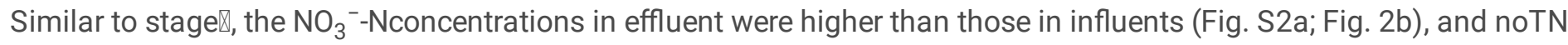
removal was observed (Fig. S2), indicating thatdenitrificationwas still inhibited, regardless of increasing $\mathrm{NH}_{4}{ }^{+}-\mathrm{N}$ concentrations.

\section{Performances ofSABRsin treatingenclosed surface waters}

\section{Condition withoutbiodegradable organic matter}

Water cycling within SABRs can improve the DO in enclosed surface waters (Fig. 4a). DO in control declined slightlyfrom $6.00 \mathrm{mgL}^{-1}$ to $3.50 \mathrm{mgL}^{-1}$ duringthe initial10days, then decreased to $0.50 \mathrm{mgL}^{-1}$ within 3 days. However,DO values by water cycling were above $9.00 \mathrm{mgL}^{-1}$ during the whole stage, and DO values in four SABRs all declining from $7.90-8.90 \mathrm{mgL}^{-1}$ to $3.50-5.50 \mathrm{mgL}^{-1}$ within 8 days, then slowly increased to $10.00 \mathrm{mgL}^{-1}$. 
In the absence of organic matter, $\mathrm{NH}_{4}{ }^{+}-\mathrm{N}$ can be effectively removed by water cycling. It took 16 days to remove $\mathrm{NH}_{4}{ }^{+}-\mathrm{N}$ by water cycling. When combined with the SABRs, the $\mathrm{NH}_{4}{ }^{+}$-Nremoval time can be reduced to 9 days (Fig. $\left.4 \mathrm{c}\right) \cdot \mathrm{NH}_{4}{ }^{+}{ }^{-}$ Nconcentrationsincontrol declined slightly from $14.22 \mathrm{mgL}^{-1}$ to $8.14 \mathrm{mgL}^{-1}$ without $\mathrm{NO}_{2}{ }^{-}{ }^{-} \mathrm{N}$ accumulations. On the contrary,both water cycling and SABRstreatments had $\mathrm{NO}_{2}{ }^{-}-\mathrm{N}$ accumulations, and $\mathrm{NO}_{2}{ }^{-}-\mathrm{N}$ concentrationsincreased firstly andthen declinedrapidly(Fig.4d). The highest $\mathrm{NO}_{2}{ }^{-}-\mathrm{N}$ concentration by water cyclingwas $8.56 \mathrm{mgL}^{-1}\left(16^{\text {th }}\right.$ day), and much higher than those by $\operatorname{SABRs}\left(5.08 \mathrm{mgL}^{-1}\right.$ on $7^{\text {th }}$ day, $7.49 \mathrm{mgL}^{-1}$ on $8^{\text {th }}$ day, $6.31 \mathrm{mgL}^{-1}$ on ${ }^{\text {th }}$ day, and $8.27 \mathrm{mgL}^{-1} \mathrm{on}^{\text {th }}$ day, respectively). These results revealed that biofilms in SABRspromoted nitrification and reducedpurification time.

Although the cultured biofilms had nitrification ability, it still needed2 days to activate nitrification to treat surface water containinga high concentration of $\mathrm{NH}_{4}{ }^{+}-\mathrm{N}(\mathrm{Fig} .4 \mathrm{c}, \mathrm{d}, \mathrm{e})$. This result consistsof that nitrificationstarted after 46 hours when the initial $\mathrm{NH}_{4}{ }^{+}-\mathrm{N}$ concentrationincreased to $8.10 \mathrm{mg} \mathrm{L}^{-1}$ in TayNinh River water(Le et al. 2019). In other words, the biofilms cultured by urban lake waters can be used in the stagnant waters treatment, and it needed time to activate the microbial activity as the pollutant concentration in enclosed surface water was much higher than urban lake waters,even though the biofilms had surfersuddenly increase of $\mathrm{NH}_{4}{ }^{+}-\mathrm{N}$ concentrations. Thus the limited nitrificationcapacity of biofilms may be the reason for high DO values at the beginning of the experiment (Fig. 4a).

\section{Conditionwithbiodegradable organic matterpresent}

In control, the organic matter ledto a decline of $\mathrm{DO}$ to $0 \mathrm{mgL}^{-1}$ during the initial5 days, while DO in four SABRs increased slightlyandthen declined to $2.00-3.10 \mathrm{mgL}^{-1}$ within 2 days, followed byan increase to $8 \mathrm{mgL}^{-1}$ (Fig. $5 \mathrm{a}$ ). Within the same time, DOC concentrations in controldecreased from $59.56 \mathrm{mgL}^{-1}$ to $8.57 \mathrm{mgL}^{-1}$ within 11 days, while it took only $5-6$ days to removethe biodegradable organic matters bywater cycling andSABRs(Fig.5b).

In the presence of organic matter, the time for $\mathrm{NH}_{4}{ }^{+}-\mathrm{N}$ removal by SABRs needed more than 22 days, which was much

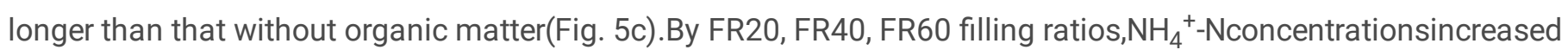
slightlywithin initial2days, then declined and became stable at $10.04 \pm 0.41 \mathrm{mgL}^{-1}$ (laggedfor 8-11 days), ultimatelydecreasedto $0.46-2.59 \mathrm{mgL}^{-1}$. However, $\mathrm{NH}_{4}{ }^{+}-\mathrm{Nconcentrationin} \mathrm{FR80} \mathrm{was} \mathrm{stabled} \mathrm{and} \mathrm{lagged} \mathrm{for} 7$ days before decliningto $0.54 \mathrm{mgL}^{-1}$. In control, $\mathrm{NH}_{4}{ }^{+}$-Nconcentrationstabled at $11.13 \pm 0.88 \mathrm{mgL}^{-1}$ at the end of the experiment,and only $21.73 \%$ was removed (Fig.5c). Surprisingly, $\mathrm{NH}_{4}{ }^{+}$-Nwas also removed by water cyclingunder organic conditions, which may be becausethe organic mattersbenefitedmicrobe growth, and attached biofilms were formed on the wave zone.In summary, the organic matters in enclosed surface waters inhibited $\mathrm{NH}_{4}{ }^{+}-\mathrm{N}$ removal and prolonged the $\mathrm{NH}_{4}{ }^{+}-$ Nremoval time.

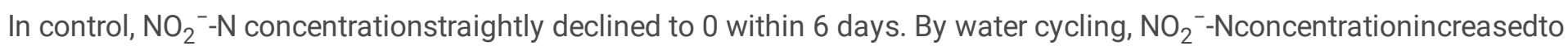
$2.29 \mathrm{mgL}^{-1}$ within 17 days then declined to 0 in 5 days (Fig. $5 \mathrm{~d}$ ). While the changes of $\mathrm{NO}_{2}{ }^{-}-\mathrm{N}^{-}$concentrations in SABRs showeda bimodal pattern, with accumulationsduring initial 6 days and then declined, followed by a second increase and decline tendency, which were different from the results in the conditionwithout organic matters(Fig. 4d). Previous studies showed that low organic loading was favorable fornitrification(Luo and Meng 2020). But $\mathrm{NH}_{4}{ }^{+}-\mathrm{NandNO}_{2}{ }^{-}-$

Nconcentrations in FR20, FR40, and FR60increasedduring initial4 days, which was in accordance withdissimilatory nitrate reductionto ammonium (DNRA)(Carlson et al. 2020; Srinandan et al. 2012).Thus, DNRA was suspected to occur when there were abundant biodegradable organic matters in this study. When organic matterswere used up after 6 days, the subsequent decline of $\mathrm{NO}_{2}{ }^{-}{ }^{-} \mathrm{Nconcentrationwas} \mathrm{due} \mathrm{tothe} \mathrm{transformation} \mathrm{of} \mathrm{NO}_{2}{ }^{-}$-Ninto $\mathrm{NO}_{3}{ }^{-}{ }^{-} \mathrm{N}(\mathrm{Fig}$. 5d). The secondincrease and decline of $\mathrm{NO}_{2}{ }^{-}-\mathrm{N}$ concentrationsin four SABRs were similartothe result of no organic mattercondition (Fig. 4d) and ascribed to the nitrification.

Page $7 / 18$ 
In control, biodegradable organic matters led to low DO,accompaniedby $100 \%$ removal of $\mathrm{NO}_{3}{ }^{-}{ }^{-} \mathrm{Nin} 5$ days. While $\mathrm{NO}_{3}{ }^{-}$Nconcentrationsin SABRs only declined in the initial few days when DO were low (Fig. 5a, e).TN in controlwas removed by $37.56 \%$, and much higher thanby using water cycling and SABRs (removed by $8.62 \%, 11.79 \%, 7.78 \%, 8.02 \%, 9.94 \%$ in FR20, FR40, FR60, FR80, and water cycling, respectively) (Fig.S3b). These results revealedthatdenitrifying microbeswere abundant in actual surface water, and denitrification can be easily achieved when DO was low. It also implied that the addition of nitrate can induce denitrification in black-odorous waterbodies without any other treatment.

The results in Fig. 6 showed that mixing the effluent of SABR with the untreated surface waters could eliminate the produced $\mathrm{NO}_{3}{ }^{-} \mathrm{N}$ (Fig. 6b, c, d). But different mix ratios have different results. By low mix ratios (10\% and $\left.20 \%\right), \mathrm{NO}_{3}{ }^{-}-\mathrm{N}$

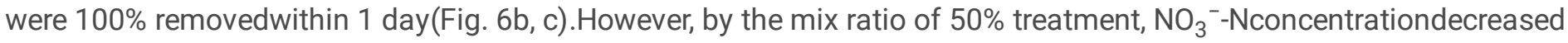
rapidlyfrom $5.94 \mathrm{mg} / \mathrm{L}$ to $3.66 \mathrm{mgL}^{-1}$ within 1 day andstabled at $3.20 \mathrm{mgL}^{-1}$ (Fig. $6 \mathrm{~d}$ ), simultaneouslythe $\mathrm{NO}_{2}{ }^{-}$ Nconcentration increased from $0.48 \mathrm{mgL}^{-1}$ to $4.07 \mathrm{mgL}^{-1}$, asthe organic matter was not enough fordenitrification. Thus TN removal by $50 \%$ mix ratio (9.9\%)was lower than $20 \%$ mix ratio (19\%) and $10 \%$ mix ratio (15\%) (Fig.6). Therefore, in order to remove TN to the maximum extent, it is necessary to quantify the biodegradable organic matter in closed surface waters.

As stated above, denitrification could occur naturallyby mixing the effluent of SABR with the surrounding-untreated surface waters. Thuspartition the enclosed-surface waters into two parts, with one part treated by SABRto removeorganic matters and $\mathrm{NH}_{4}{ }^{+}-\mathrm{N}$, then transfer the produced $\mathrm{NO}_{3}{ }^{-}-\mathrm{N}$ to another part without aeration, andthis sequencing treatment may be an economicalway to tackle those black-odorous waterbodies when it contains high organic matters.Moreover, the produced $\mathrm{NO}_{3}{ }^{-}$-Ncan promote the biodegradation ofhazardous organic chemicals(Wang et al. 2019) and improve the oxidation-reduction potential of sediment (Li et al. 2019)in another part of surface waters.

\section{Other water quality parameters}

Biological conversation of $\mathrm{NH}_{4}{ }^{+}-\mathrm{Nto} \mathrm{NO}_{\mathrm{x}}-\mathrm{N}$ often led to $\mathrm{pH}$ decline, but in the continue experiment in this study, $\mathrm{pH}$ in effluents was higher than influent (Fig.2b). It may due to the low flow influent or high HRT, and buffer effect of surface waters. Moreover, the fine wires used in this study can lead to a pH increase due to Fe corrosion(Di Capua et al. 2019). While in enclosed surface waters, nitrificationled to the decrease of $\mathrm{pH}$ (Fig. 4b;Fig. S3a),promoted the releaseof Fe ${ }^{2+}$ and $\mathrm{Fe}^{3+}$ fromfine wires then precipitates with phosphorus. Thus the removal of $\mathrm{PO}_{4}{ }^{3-}-\mathrm{P}$ in the batch experiments was due to the fine wires(Fig. 4f; Fig. S3c).

\section{Conclusions}

A novel biofilm reactor (SABR) was constructed for urban surface waterspurification. Biofilms were formed on polyurethane sponges by the indigenous microorganisms in urban surface waters. SABRs could improve DO and efficiently remove $\mathrm{NH}_{4}{ }^{+}$-Ninlake waters, but $\mathrm{NH}_{4}{ }^{+}$-Nwasonly transformed into $\mathrm{NO}_{3}{ }^{-} \mathrm{N}$. Increasing the filling ratiosof biocarriersreduced DO but did not affect $\mathrm{NH}_{4}{ }^{+}-\mathrm{N}$ and $\mathrm{TN}$ removal. SABRswere stable to the continued influent and showed resilience when facing various intermittent increases of $\mathrm{NH}_{4}{ }^{+}-\mathrm{Nand}^{-} \mathrm{NO}_{2}-\mathrm{N}$ concentrationsin influent. While biodegradable organic matters in enclosed-surface waterscan inhibit $\mathrm{NH}_{4}{ }^{+}-\mathrm{N}$ removal by SABRs and prolong the purificationtime. The produced $\mathrm{NO}_{3}{ }^{-}-\mathrm{N}$ inSABRs wasrapidly removed through mixing with the untreated surface waters whenbiodegradableorganic matterswere present abundantly. Therefore, the developed new bioreactor provided one practical and efficient way for treatment of urban surface waters.

\section{Declarations}

Ethics approval and consent to participate

Page $8 / 18$ 
Not applicable.

\section{Consent for publication}

Not applicable.

\section{Availability of data and materials}

All data generated or analyzed duringthis study are included in this published article.

\section{Competing interests}

The authors declare no competing interests.

\section{Funding}

This study was supported by grants from the National SpecialProgram of Water Environment (2017ZX07204005).

\section{Author contributions}

Shangwei He: Methodology, Investigation, Formal analysis, Writing -Original Draft. Na Song: Writing - Review \&Editing. Zongbao Yao: Writing - Review \&Editing. Helong Jiang: Conceptualization, Resources, Writing - Review \&Editing, Funding acquisition.

\section{References}

1. Austin, D., Vazquez-Burney, R., Dyke, G. and King, T. (2019) Nitrification and total nitrogen removal in a superoxygenated wetland. Sci. Total. Environ 652, 307-313. https://doi.org/10.1016/j.scitotenv.2018.10.110

2. Ballantine, K.A., Groffman, P.M., Lehmann, J. and Schneider, R.L. (2014) Stimulating nitrate removal processes of restored wetlands. Environ. Sci. Technol 48(13), 7365-7373. https://doi.org/10.1021/es500799v

3. Berga, M., Zha, Y., Székely, A.J. and Langenheder, S. (2017) Functional and Compositional Stability of Bacterial Metacommunities in Response to Salinity Changes. Front. Microbiol. 8, 1-11. https://doi.org/10.3389/fmicb.2017.00948

4. Boog, J., Nivala, J., Aubron, T., Mothes, S., van Afferden, M. and Muller, R.A. (2018) Resilience of carbon and nitrogen removal due to aeration interruption in aerated treatment wetlands. Sci. Total. Environ 621, 960-969. https://doi.org/10.1016/j.scitotenv.2017.10.131

5. Cabrol, L., Malhautier, L., Poly, F., Roux, X.L., Lepeuple, A.S. and Fanlo, J.L. (2012) Resistance and resilience of removal efficiency and bacterial community structure of gas biofilters exposed to repeated shock loads. Bioresour. Technol 123, 548-557. https://doi.org/10.1016/j.biortech.2012.07.033

6. Cao, J., Sun, Q., Zhao, D., Xu, M., Shen, Q., Wang, D., Wang, Y. and Ding, S. (2020) A critical review of the appearance of black-odorous waterbodies in China and treatment methods. J. Hazard. Mater 385, 121511. https://doi.org/10.1016/j.jhazmat.2019.121511

7. Carlson, H.K., Lui, L.M., Price, M.N., Kazakov, A.E., Carr, A.V., Kuehl, J.V., Owens, T.K., Nielsen, T., Arkin, A.P. and Deutschbauer, A.M. (2020) Selective carbon sources influence the end products of microbial nitrate respiration. ISME. J 14(8), 2034-2045. https://doi.org/10.1038/s41396-020-0666-7

8. Chang, M., Wang, Y., Pan, Y., Zhang, K., Lyu, L., Wang, M. and Zhu, T. (2019) Nitrogen removal from wastewater via simultaneous nitrification and denitrification using a biological folded non-aerated filter. Bioresour. Technol 289, 121696. https://doi.org/10.1016/j.biortech.2019.121696 
9. Cho, K., Shin, S.G., Lee, J., Koo, T., Kim, W. and Hwang, S. (2016) Nitrification resilience and community dynamics of ammonia-oxidizing bacteria with respect to ammonia loading shock in a nitrification reactor treating steel wastewater. J. Biosci. Bioeng 122(2), 196-202. https://doi.org/10.1016/j.jbiosc.2016.01.009

10. Di Capua, F., Pirozzi, F., Lens, P.N.L. and Esposito, G. (2019) Electron donors for autotrophic denitrification. Chem. Eng. J. 362, 922-937. https://doi.org/10.1016/j.cej.2019.01.069

11. Fan, C., Wang, P., Zhou, W., Wu, S., He, S., Huang, J. and Cao, L. (2018) The influence of phosphorus on the autotrophic and mixotrophic denitrification. Sci. Total. Environ 643, 127-133.

https://doi.org/10.1016/j.scitotenv.2018.06.185

12. Feng, Q., Wang, Y., Wang, T., Zheng, H., Chu, L., Zhang, C., Chen, H., Kong, X. and Xing, X.H. (2012) Effects of packing rates of cubic-shaped polyurethane foam carriers on the microbial community and the removal of organics and nitrogen in moving bed biofilm reactors. Bioresour. Technol 117, 201-207.

https://doi.org/10.1016/j.biortech.2012.04.076

13. Funes, A., Martinez, F.J., Alvarez-Manzaneda, I., Conde-Porcuna, J.M., de Vicente, J., Guerrero, F. and de Vicente, I. (2018) Determining major factors controlling phosphorus removal by promising adsorbents used for lake restoration: A linear mixed model approach. Water Res 141, 377-386. https://doi.org/10.1016/j.watres.2018.05.029

14. Guo, W.S., Ngo, H.H., Dharmawan, F. and Palmer, C.G. (2010) Roles of polyurethane foam in aerobic moving and fixed bed bioreactors. Bioresour. Technol 101(5), 1435-1439. https://doi.org/10.1016/j.biortech.2009.05.062

15. He, S., Zhang, L., Zhang, C., Liu, B., Shao, J. and Li, P. (2018) Annual variations and the cause of the ammonia nitrogen concentration in effluent of a chemical industrial wastewater treatment. Chem. Ind. Eng. Prog 37(9), 3691 3698. https://doi.org/10.16085/j.issn.1000-6613.2017-2482

16. Hobbie, S.E., Finlay, J.C., Janke, B.D., Nidzgorski, D.A., Millet, D.B. and Baker, L.A. (2017) Contrasting nitrogen and phosphorus budgets in urban watersheds and implications for managing urban water pollution. P. Natl. A. Sci. 114(16), 4177-4182. https://doi.org/10.1073/pnas.1618536114

17. Huang, X., Li, W., Zhang, D. and Qin, W. (2013) Ammonium removal by a novel oligotrophic Acinetobacter sp. Y16 capable of heterotrophic nitrification-aerobic denitrification at low temperature. Bioresour. Technol 146, 44-50. https://doi.org/10.1016/j.biortech.2013.07.046

18. Jia, Z., Liu, T., Xia, X. and Xia, N. (2016) Effect of particle size and composition of suspended sediment on denitrification in river water. Sci. Total. Environ 541, 934-940. https://doi.org/10.1016/j.scitotenv.2015.10.012

19. Koehler, B., von Wachenfeldt, E., Kothawala, D. and Tranvik, L.J. (2012) Reactivity continuum of dissolved organic carbon decomposition in lake water. J. Geophys. Res. Biogeosci. 117, 1-15. https://doi.org/10.1029/2011jg001793

20. Le, T.T.H., Fettig, J. and Meon, G. (2019) Kinetics and simulation of nitrification at various pH values of a polluted river in the tropics. Ecohydro. Hydrobio 19(1), 54-65. https://doi.org/10.1016/j.ecohyd.2018.06.006

21. Li, W., Zhang, S., Zhang, L., Li, X., Wang, F., Li, G., Li, J. and Li, W. (2019) In-situ remediation of sediment by calcium nitrate combined with composite microorganisms under low-DO regulation. Sci. Total. Environ 697, 134109. https://doi.org/10.1016/j.scitotenv.2019.134109

22. Liu, J., Wang, F., Liu, W., Tang, C., Wu, C. and Wu, Y. (2016) Nutrient removal by up-scaling a hybrid floating treatment bed (HFTB) using plant and periphyton: From laboratory tank to polluted river. Bioresour. Technol 207, 142-149. https://doi.org/10.1016/j.biortech.2016.02.011

23. Liu, T., Xia, X., Liu, S., Mou, X. and Qiu, Y. (2013) Acceleration of Denitrification in Turbid Rivers Due to Denitrification Occurring on Suspended Sediment in Oxic Waters. Environ. Sci. Technol 47(9), 4053-4061. https://doi.org/10.1021/es304504m

24. Luo, X. and Meng, F. (2020) Roles of Organic Matter-Induced Heterotrophic Bacteria in Nitritation Reactors: Ammonium Removal and Bacterial Interactions. ACS Sustain. Chem.Eng. 8(9), 3976-3985. https://doi.org/10.1021/acssuschemeng.0c00241

Page 10/18 
25. Macedo, W.V., Santos, C.E.D., Guerrero, R.B.S., Sakamoto, I.K., Amorim, E.L.C., Azevedo, E.B. and Damianovic, M. (2019) Establishing simultaneous nitrification and denitrification under continuous aeration for the treatment of multi-electrolytes saline wastewater. Bioresour. Technol 288, 121529. https://doi.org/10.1016/j.biortech.2019.121529

26. Min, L., Zhong Sheng, Z., Zhe, L. and Hai Tao, W. (2020) Removal of nitrogen and phosphorus pollutants from water by FeCl3- impregnated biochar. Ecol. Eng. 149, 105792. https://doi.org/10.1016/j.ecoleng.2020.105792

27. Murphy, C., Rajabzadeh, A.R., Weber, K.P., Nivala, J., Wallace, S.D. and Cooper, D.J. (2016) Nitrification cessation and recovery in an aerated saturated vertical subsurface flow treatment wetland: Field studies and microscale biofilm modeling. Bioresour. Technol 209, 125-132. https://doi.org/10.1016/j.biortech.2016.02.065

28. Nsenga Kumwimba, M., Meng, F., Iseyemi, O., Moore, M.T., Zhu, B., Tao, W., Liang, T.J. and Ilunga, L. (2018) Removal of non-point source pollutants from domestic sewage and agricultural runoff by vegetated drainage ditches (VDDs): Design, mechanism, management strategies, and future directions. Sci. Total. Environ 639, 742-759. https://doi.org/10.1016/j.scitotenv.2018.05.184

29. Saeed, T., Majed, N., Khan, T. and Mallika, H. (2019) Two-stage constructed wetland systems for polluted surface water treatment. J. Environ. Manage 249, 109379. https://doi.org/10.1016/j.jenvman.2019.109379

30. SEPA, (2002) Water and Wastewater Monitoring Methods, fourth ed. Chinese Environmental Science Press, Beijing, China.

31. Shi, J., Han, Y., Xu, C. and Han, H. (2019) Enhanced biodegradation of coal gasification wastewater with anaerobic biofilm on polyurethane (PU), powdered activated carbon (PAC), and biochar. Bioresour. Technol 289, 121487. https://doi.org/10.1016/j.biortech.2019.121487

32. Srinandan, C.S., D'Souza, G., Srivastava, N., Nayak, B.B. and Nerurkar, A.S. (2012) Carbon sources influence the nitrate removal activity, community structure and biofilm architecture. Bioresour. Technol 117, 292-299.

https://doi.org/10.1016/j.biortech.2012.04.079

33. Sukias, J.P.S., Park, J.B.K., Stott, R. and Tanner, C.C. (2018) Quantifying treatment system resilience to shock loadings in constructed wetlands and denitrification bioreactors. Water Res 139, 450-461.

https://doi.org/10.1016/j.watres.2018.04.010

34. Wang, C., Wu, Y., Wang, Y., Bai, L., Jiang, H. and Yu, J. (2018a) Lanthanum-modified drinking water treatment residue for initial rapid and long-term equilibrium phosphorus immobilization to control eutrophication. Water Res 137, 173183. https://doi.org/10.1016/j.watres.2018.03.018

35. Wang, J. and Chu, L. (2016) Biological nitrate removal from water and wastewater by solid-phase denitrification process. Biotechnol. Adv. 34(6), 1103-1112. https://doi.org/10.1016/j.biotechadv.2016.07.001

36. Wang, L., Li, Y., Fan, C., Wang, P., Niu, L. and Wang, L. (2019) Nitrate addition promotes the nitrogen cycling processes under the co-contaminated tetrabromobisphenol A and copper condition in river sediment. Environ. Pollut. 251, 659667. https://doi.org/10.1016/j.envpol.2019.05.024

37. Wang, P., Jeelani, N., Zuo, J., Zhang, H., Zhao, D., Zhu, Z., Leng, X. and An, S. (2018b) Nitrogen removal during the cold season by constructed floating wetlands planted with Oenanthe javanica. Mar. Fresh. Res 69(5), 635. https://doi.org/10.1071/mf17156

38. Wen, G., Wang, T., Li, K., Wang, H., Wang, J. and Huang, T. (2019) Aerobic denitrification performance of strain Acinetobacter johnsonii WGX-9 using different natural organic matter as carbon source: Effect of molecular weight. Water Res 164, 114956. https://doi.org/10.1016/j.watres.2019.114956

39. Wu, K., Lu, K., Dai, M. and Liu, Z. (2019a) The bioavailability of riverine dissolved organic matter in coastal marine waters of southern Texas. Estuar. Coast. Shelf Sci. 231, 106477. https://doi.org/10.1016/j.ecss.2019.106477

40. Wu, Q., Hu, Y., Li, S., Peng, S. and Zhao, H. (2016) Microbial mechanisms of using enhanced ecological floating beds for eutrophic water improvement. Bioresour. Technol 211, 451-456. https://doi.org/10.1016/j.biortech.2016.03.113

Page $11 / 18$ 
41. Wu, Y., Xia, L., Yu, Z., Shabbir, S. and Kerr, P.G. (2014) In situ bioremediation of surface waters by periphytons. Bioresour. Technol 151, 367-372. https://doi.org/10.1016/j.biortech.2013.10.088

42. Wu, Z.Y., Zhao, H., Hu, X.Y., Yuan, B.L. and Fu, M.L. (2019b) Tunable porous ferric composite for effective removal of phosphate in water. Coll. Surf. A 582, 123854. https://doi.org/10.1016/j.colsurfa.2019.123854

43. Xia, L., Li, X., Fan, W. and Wang, J. (2020) Heterotrophic nitrification and aerobic denitrification by a novel Acinetobacter sp. ND7 isolated from municipal activated sludge. Bioresour. Technol 301, 122749. https://doi.org/10.1016/j.biortech.2020.122749

44. Xia, X.H., Liu Ting, Yang Zhi Feng, Greg Michalski, Liu Shao Da, Jia Zhi Mei and Bo, Z.S. (2017) Enhanced nitrogen loss from rivers through coupled nitrification-denitrification caused by suspended sediment. Sci. Total. Environ 579, 47-59. https://doi.org/10.1016/j.scitotenv.2016.10.181

45. Xiong, W. and Peng, J. (2008) Development and characterization of ferrihydrite-modified diatomite as a phosphorus adsorbent. Water Res 42(19), 4869-4877. https://doi.org/10.1016/j.watres.2008.09.030

46. Xu, H., Li, Y., Liu, J., Du, H., Du, Y., Su, Y. and Jiang, H. (2020) Photogeneration and steady-state concentration of hydroxyl radical in river and lake waters along middle-lower Yangtze region, China. Water Res 176, 115774. https://doi.org/10.1016/j.watres.2020.115774

47. Yan, L., Mu, X., Han, B., Zhang, S., Qiu, C. and Ohore, O.E. (2019) Ammonium loading disturbed the microbial food webs in biofilms attached to submersed macrophyte Vallisneria natans. Sci. Total. Environ 659, 691-698. https://doi.org/10.1016/j.scitotenv.2018.12.423

48. Yang, X., Liu, L. and Wang, S. (2019) A strategy of high-efficient nitrogen removal by an ammonia-oxidizing bacterium consortium. Bioresour. Technol 275, 216-224. https://doi.org/10.1016/j.biortech.2018.12.057

49. Yao, Z.B., Yang, L., Wang, F., Tian, L.Q., Song, N. and Jiang, H.L. (2020) Enhanced nitrate removal from surface water in a denitrifying woodchip bioreactor with a heterotrophic nitrifying and aerobic denitrifying fungus. Bioresour. Technol 303, 122948. https://doi.org/10.1016/j.biortech.2020.122948

50. Yu, L., Li, R., Delatolla, R., Zhang, R., Yang, X. and Peng, D. (2018) Natural continuous influent nitrifier immigration effects on nitrification and the microbial community of activated sludge systems. J. Environ. Sci 74, 159-167. https://doi.org/10.1016/j.jes.2018.02.021

51. Zak, D., Kronvang, B., Carstensen, M.V., Hoffmann, C.C., Kjeldgaard, A., Larsen, S.E., Audet, J., Egemose, S., Jorgensen, C.A., Feuerbach, P., Gertz, F. and Jensen, H.S. (2018) Nitrogen and Phosphorus Removal from Agricultural Runoff in Integrated Buffer Zones. Environ. Sci. Technol 52(11), 6508-6517. https://doi.org/10.1021/acs.est.8b01036

52. Zhang, L., Zhao, J., Cui, N., Dai, Y., Kong, L., Wu, J. and Cheng, S. (2015) Enhancing the water purification efficiency of a floating treatment wetland using a biofilm carrier. Environ. Sci. Pollut. Res. 23(8), 7437-7443. https://doi.org/10.1007/s11356-015-5873-9

53. Zhang, S., Wang, Y., He, W., Wu, M., Xing, M., Yang, J., Gao, N. and Pan, M. (2014) Impacts of temperature and nitrifying community on nitrification kinetics in a moving-bed biofilm reactor treating polluted raw water. Chem. Eng. J 236, 242-250. https://doi.org/10.1016/j.cej.2013.09.086

54. Zhang, X., Chen, X., Zhang, C., Wen, H., Guo, W. and Ngo, H.H. (2016) Effect of filling fraction on the performance of sponge-based moving bed biofilm reactor. Bioresour. Technol 219, 762-767. https://doi.org/10.1016/j.biortech.2016.08.031

55. Zhao, C., Wang, C.C., Li, J.Q., Wang, C.Y., Wang, P. and Pei, Z.J. (2015) Dissolved organic matter in urban stormwater runoff at three typical regions in Beijing: chemical composition, structural characterization and source identification. RSC Adv 5(90), 73490-73500. https://doi.org/10.1039/c5ra14993b

56. Zhao, Y., Yuan, Q., He, Z., Wang, H., Yan, G., Chang, Y., Chu, Z., Ling, Y. and Wang, H. (2019) Influence of Carrier Filling Ratio on the Advanced Nitrogen Removal from Wastewater Treatment Plant Effluent by Denitrifying MBBR. Int. J. Environ. Res. Public Health 16(18), 3244. https://doi.org/10.3390/ijerph16183244

Page 12/18 
57. Zhong, J., Liu, G., Fan, C., Bai, X., Li, B., Zhang, L. and Ding, S. (2009) Environmental effect of sediment dredging in lake: $\otimes$. Influence of dredging on denitrification in sediments. J. Lake. Sci 21(4), 465 - 473.

58. Zhou, S., Huang, T., Zhang, H., Zeng, M., Liu, F., Bai, S., Shi, J., Qiu, X. and Yang, X. (2016) Nitrogen removal characteristics of enhanced in situ indigenous aerobic denitrification bacteria for micro-polluted reservoir source water. Bioresour. Technol 201, 195-207. https://doi.org/10.1016/j.biortech.2015.11.041

59. Zhou, S., Sun, Y., Zhang, Y., Huang, T., Zhou, Z., Li, Y. and Li, Z. (2020) Pollutant removal performance and microbial enhancement mechanism by water-lifting and aeration technology in a drinking water reservoir ecosystem. Sci. Total. Environ 709, 135848. https://doi.org/10.1016/j.scitotenv.2019.135848

60. Zou, S.Q., Yao, S. and Ni, J.R. (2014) High-efficient nitrogen removal by coupling enriched autotrophic-nitrification and aerobic-denitrification consortiums at cold temperature. Bioresour. Technol 161, 288-296.

https://doi.org/10.1016/j.biortech.2014.03.066

\section{Tables}

Table1 Operation conditions at different stages

\begin{tabular}{|c|c|c|c|c|c|c|c|}
\hline & \multicolumn{5}{|c|}{ Influent water characters } & \multirow{2}{*}{$\begin{array}{l}\text { DO supplied } \\
\text { by }\end{array}$} & \multirow[t]{2}{*}{ Mode } \\
\hline & $\begin{array}{l}\mathrm{NH}_{4}{ }^{+}-\mathrm{N} \\
(\mathrm{mg} / \mathrm{L})\end{array}$ & $\begin{array}{l}\mathrm{NO}_{2}^{-}- \\
\mathrm{N}(\mathrm{mg} / \mathrm{L})\end{array}$ & $\begin{array}{l}\mathrm{NO}_{3}^{-}- \\
\mathrm{N}(\mathrm{mg} / \mathrm{L})\end{array}$ & $\begin{array}{l}\mathrm{PO}_{4}^{3-}- \\
\mathrm{P}(\mathrm{mg} / \mathrm{L})\end{array}$ & $\mathrm{T}\left({ }^{\circ} \mathrm{C}\right)$ & & \\
\hline $\begin{array}{l}\text { Stage[a ( } 70 \\
\text { days) }\end{array}$ & $0.05-0.49$ & $0.00-0.13$ & $0.09-1.50$ & $0-0.10$ & $\begin{array}{l}14.4- \\
25.8\end{array}$ & Air & Continue \\
\hline $\begin{array}{l}\text { Stage[b ( } 37 \\
\text { days) }\end{array}$ & $0.05-0.56$ & $0.01-0.19$ & $0.34-1.79$ & $0.01-0.13$ & $\begin{array}{l}22.4- \\
25.8\end{array}$ & $\begin{array}{l}\text { Water } \\
\text { cycling }\end{array}$ & Continue \\
\hline $\begin{array}{l}\text { Stage } \mathrm{L} \text { ( } 55 \\
\text { days) }\end{array}$ & $0.34-4.69$ & $0.00-1.08$ & $0.74-5.49$ & $0.01-0.12$ & $\begin{array}{l}20.5- \\
26.2\end{array}$ & $\begin{array}{l}\text { Water } \\
\text { cycling }\end{array}$ & Continue \\
\hline $\begin{array}{l}\text { Stage } 0^{*} \text { ( } 23 \\
\text { days) }\end{array}$ & 15.00 & 0.15 & 1.53 & 0.06 & $\begin{array}{l}20.4- \\
24.6\end{array}$ & $\begin{array}{l}\text { Water } \\
\text { cycling }\end{array}$ & Continue \\
\hline $\begin{array}{l}\text { Stage } 0^{*} \text { ( } 20 \\
\text { days) }\end{array}$ & $14.22 \pm 1.15$ & $0.05 \pm 0.00$ & $1.85 \pm 0.10$ & $0.04 \pm 0.00$ & $\begin{array}{l}11.4- \\
18.2\end{array}$ & $\begin{array}{l}\text { Water } \\
\text { cycling }\end{array}$ & Batch \\
\hline $\begin{array}{l}\text { Stage } 0^{*}(22 \\
\text { days) }\end{array}$ & $14.22 \pm 0.30$ & $0.43 \pm 0.10$ & $3.57 \pm 0.10$ & $0.43 \pm 0.06$ & $\begin{array}{l}6.5- \\
14.6\end{array}$ & $\begin{array}{l}\text { Water } \\
\text { cycling }\end{array}$ & Batch \\
\hline
\end{tabular}

*Influent water charactersat the beginning of the experiments.

Table2 Function resilience of four SABRs (Days needed to recover by increased suddenly of $\mathrm{NH}_{4}{ }^{+}-\mathrm{N}^{2}$ and $\mathrm{NO}_{2}{ }^{-} \mathrm{N}$ in influent) 


\begin{tabular}{|c|c|c|c|c|c|c|c|c|c|c|c|c|c|c|c|c|}
\hline & \multicolumn{8}{|c|}{$\mathrm{NH}_{4}^{+}-\mathrm{N}$ (days needed to recover to below $0.1 \mathrm{mg} / \mathrm{L}$ ) } & \multicolumn{8}{|c|}{$\mathrm{NO}_{2}-\mathrm{N}$ (days neededto recover to below $0.05 \mathrm{mg} / \mathrm{L}$ ) } \\
\hline & \multicolumn{7}{|c|}{ Stage $\nabla$} & \multirow{2}{*}{$\begin{array}{l}\text { Stage } \\
\text { a }\end{array}$} & \multicolumn{7}{|c|}{ 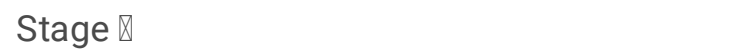 } & \multirow{2}{*}{ Stage } \\
\hline & $1 \mathrm{st}$ & 2nd & $3 r d$ & 4th & 5 th & 6th & 7th & & $1 \mathrm{st}$ & 2nd & $3 r d$ & 4th & 5 th & 6th & 7th & \\
\hline FR20 & 6 & 2 & 1 & 0 & 4 & 1 & 2 & 8 & 8 & 3 & 0 & 8 & 3 & 0 & 2 & 4 \\
\hline FR40 & 4 & 2 & 1 & 0 & 4 & 1 & 1 & 8 & 7 & 2 & 0 & 1 & 1 & 1 & 0 & 4 \\
\hline FR60 & 6 & 4 & 1 & 0 & 4 & 1 & 2 & 7 & 6 & 2 & 0 & 3 & 0 & 0 & 0 & 4 \\
\hline FR80 & 4 & 3 & 1 & 0 & 4 & 1 & 1 & 7 & 4 & 0 & 0 & 2 & 0 & 0 & 0 & 6 \\
\hline
\end{tabular}

\section{Figures}

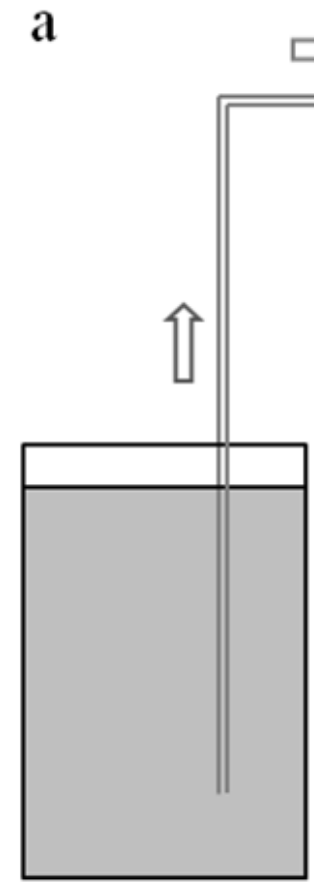

Storage tank

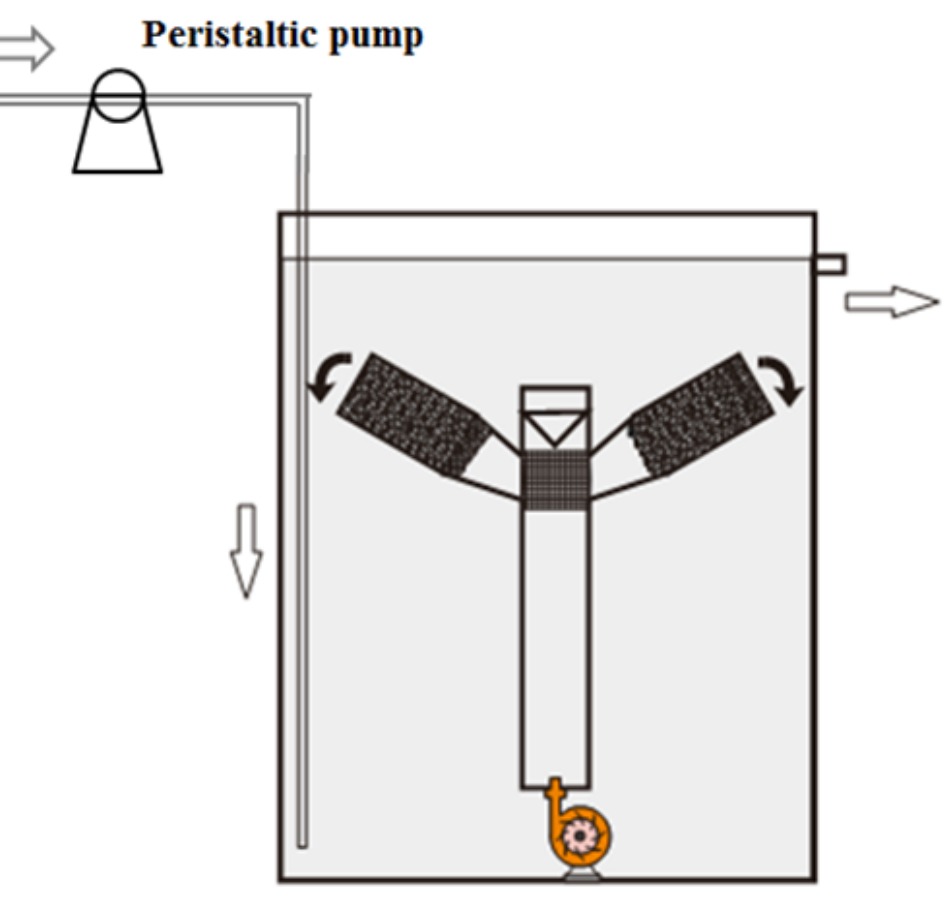

Purification tank

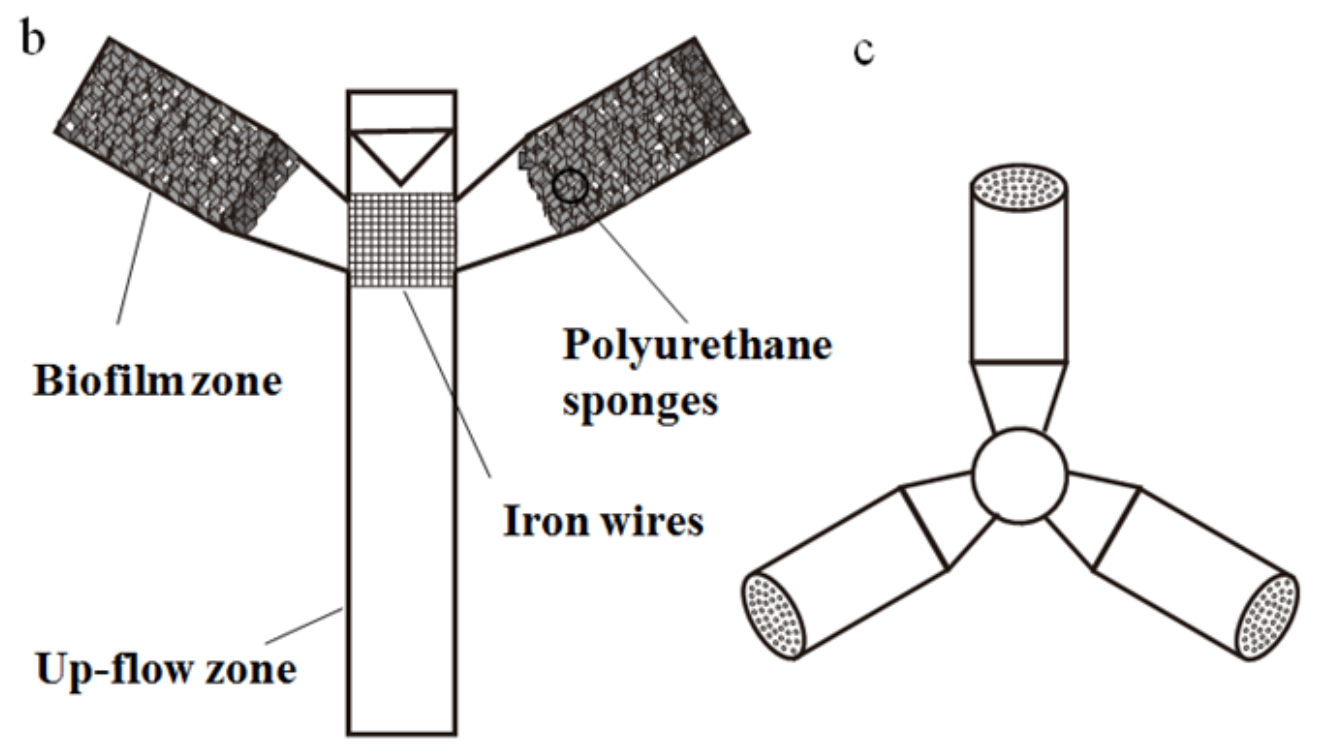


Figure 1

Schematic diagram of the experimental set-up (a) and configurations of the sponge-based aerobic biofilm reactor (b, c)
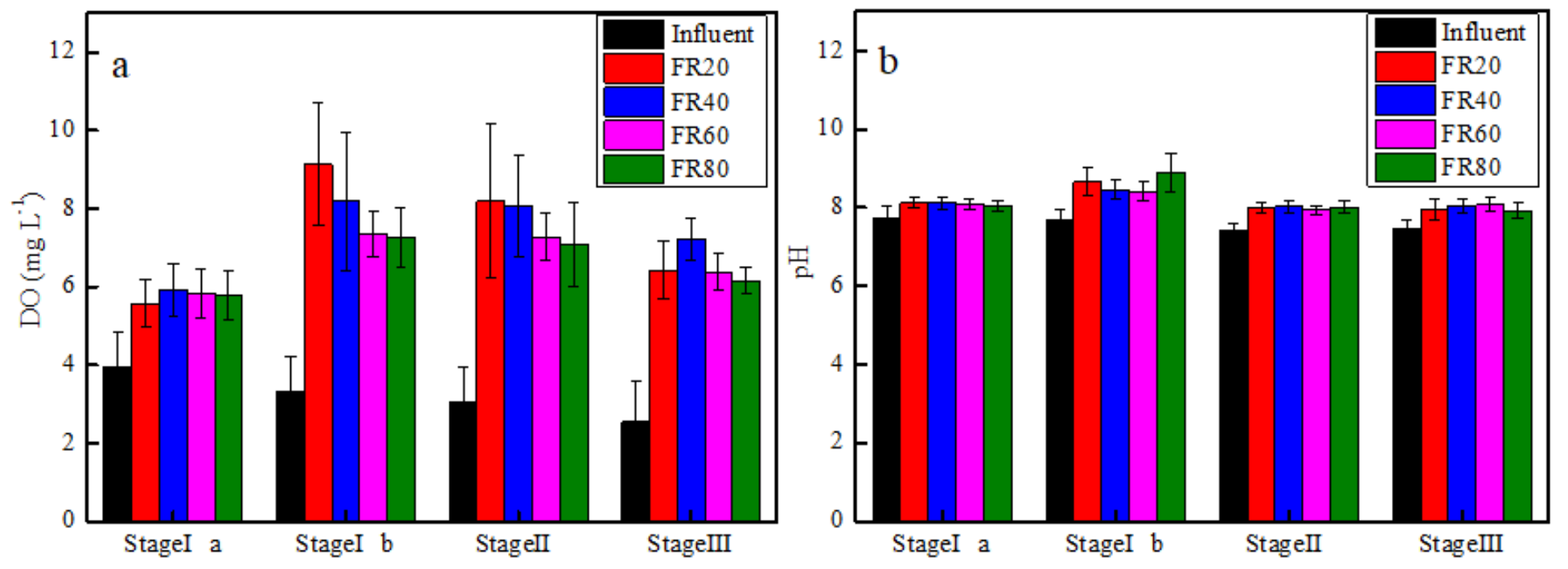

Figure 2

$\mathrm{DO}$ and $\mathrm{pH}$ from stage $\triangle$ to stage $\otimes$ (Filling ratios of SABRs by $20 \%, 40 \%, 60 \%, 80 \%$ were referred to as FR20, FR40, FR60, and FR80, respectively)
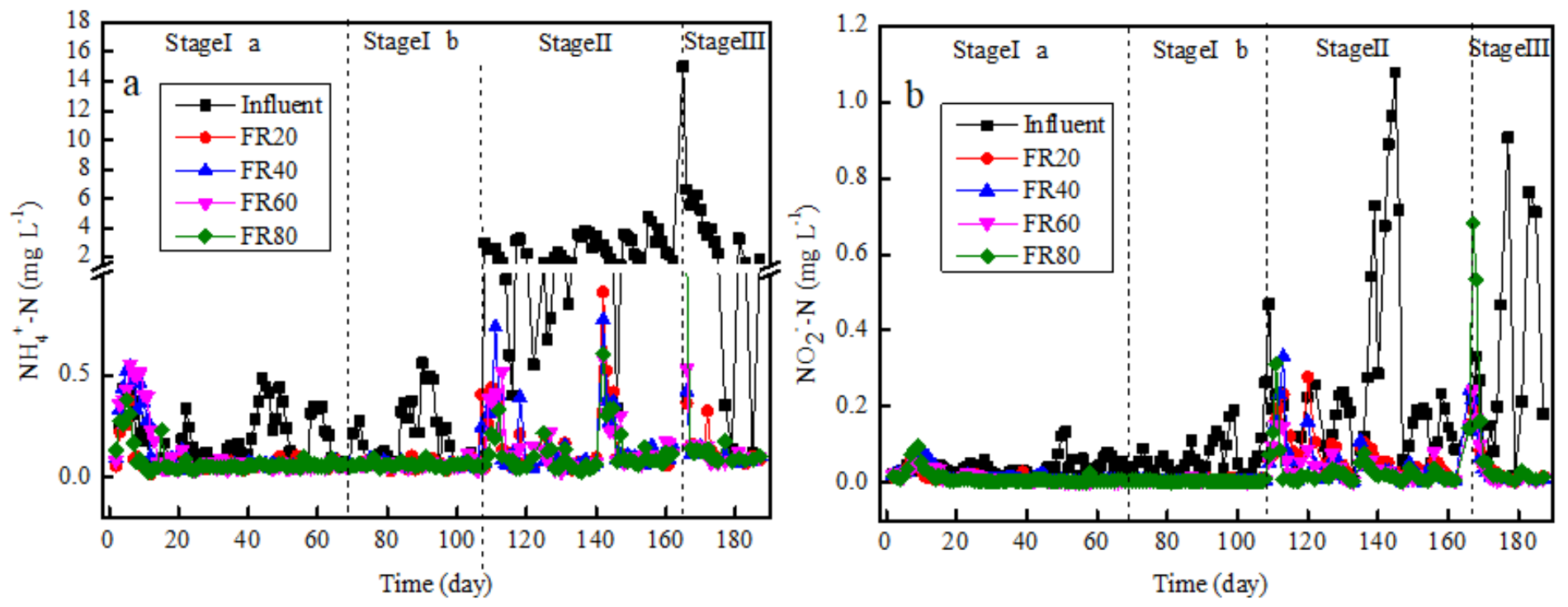

Figure 3

NH4+-N and NO2--Nconcentrations in continuous experiments by using SABRs (Filling ratios by $20 \%, 40 \%, 60 \%, 80 \%$ were referred to as FR20, FR40, FR60, and FR80,respectively) 

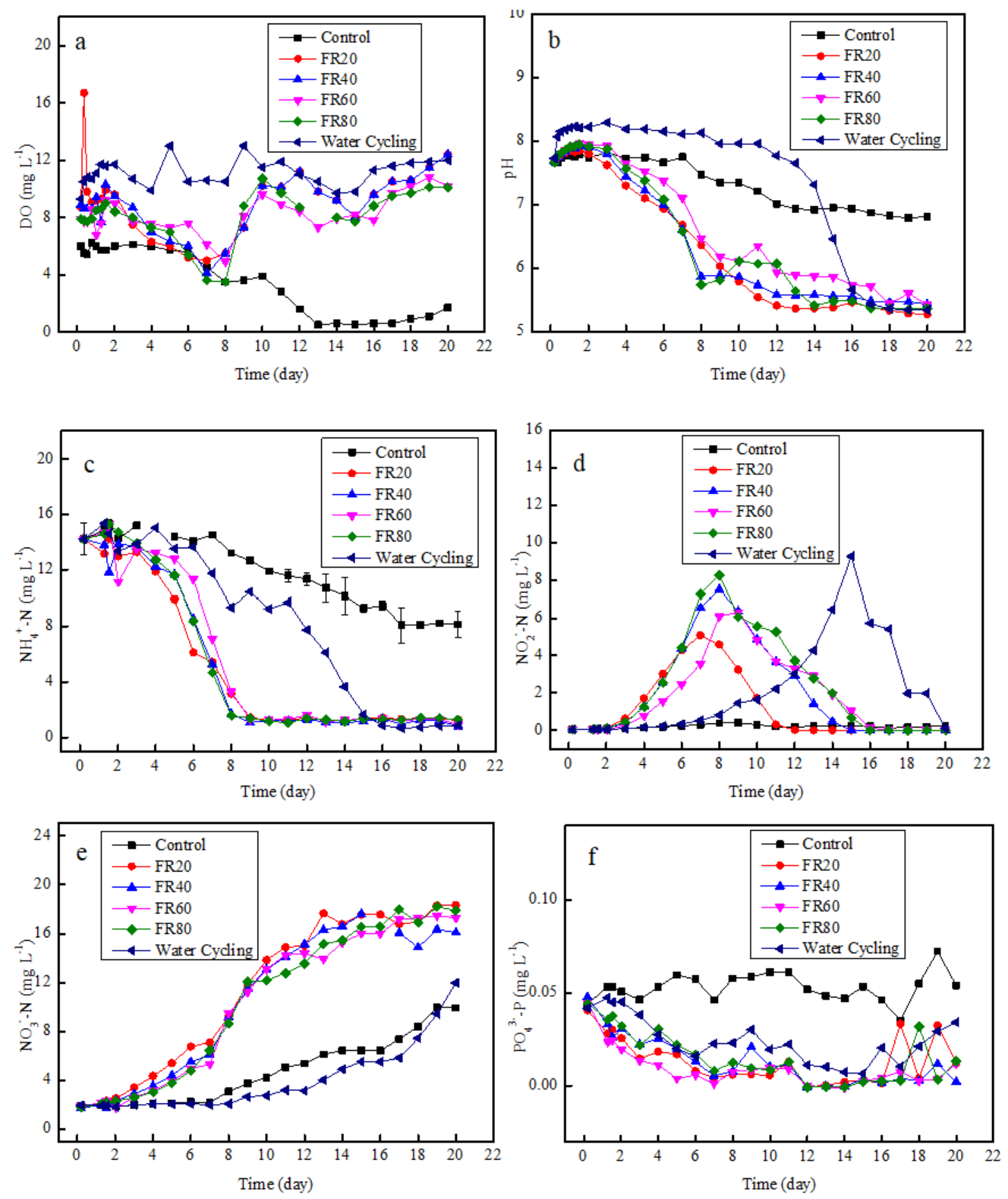

Figure 4

Purificationperformances by different treatments (no organic matters presented) 

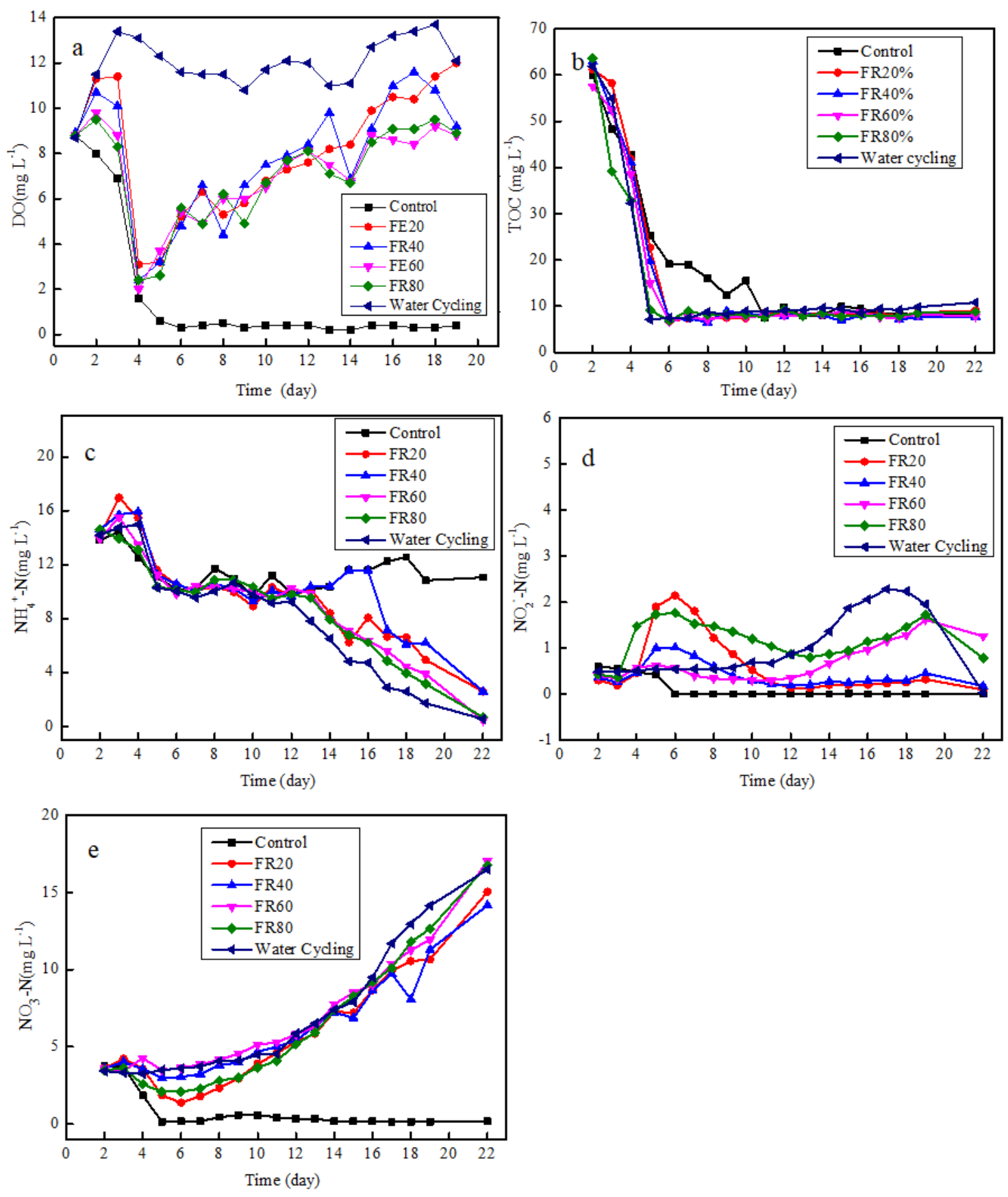

Figure 5

Purificationperformances by different treatments (organic matters presented) 

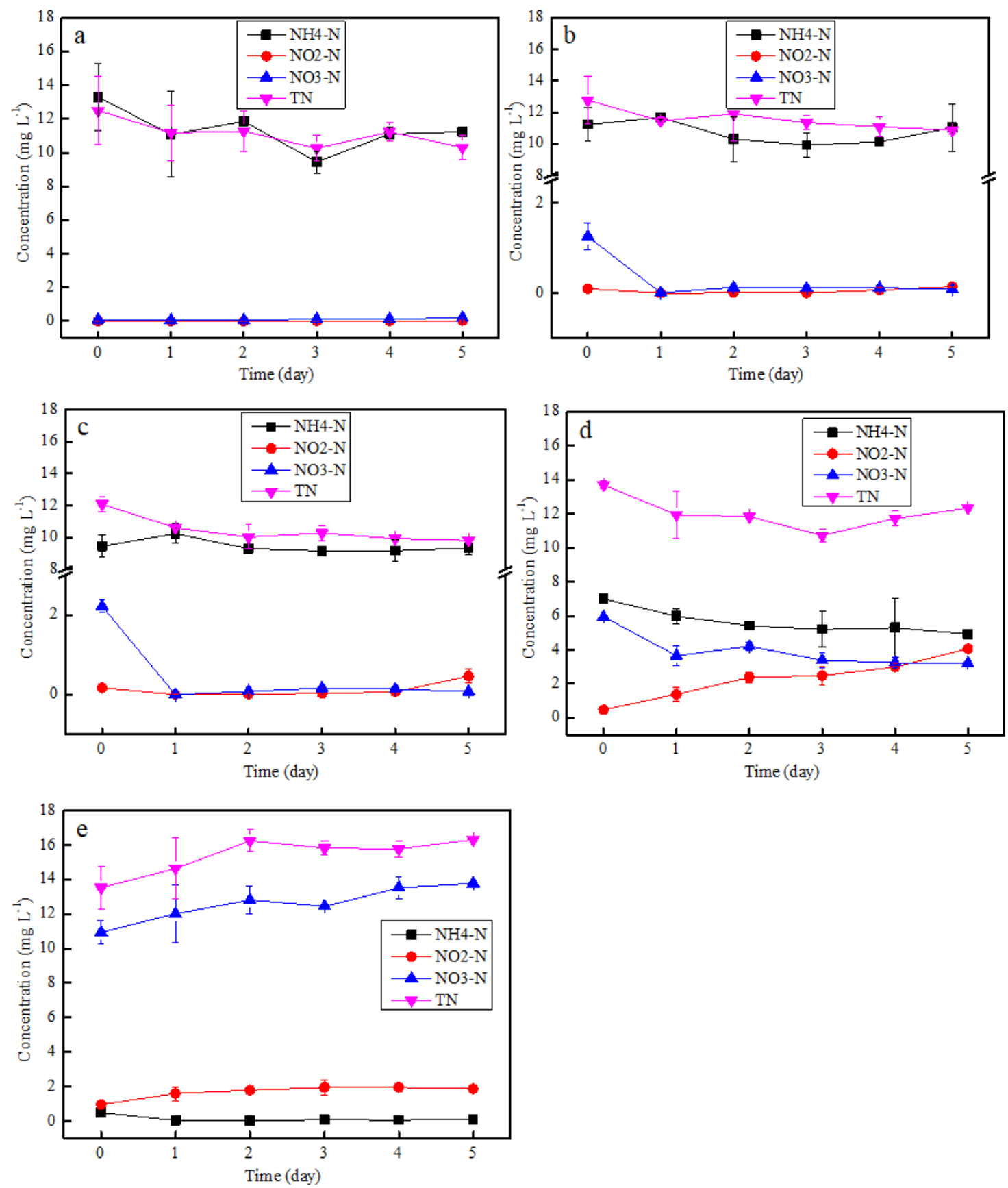

Figure 6

Performances of different volume mix ratios by effluent of SABR/untreated surface water (a. $0 ;$ b, 10\%; c, 20\%; d, 50\%; e, $100 \%)$

\section{Supplementary Files}

This is a list of supplementary files associated with this preprint. Click to download.

- Supportinglnformation.docx 